\title{
Journalistic branding via Twitter: researches synthesis and case interviews
}

\author{
Cholticha Rodgunpai ${ }^{1},{ }^{*}$ Jantima Kheokao ${ }^{2}$ \\ 1. D.ComArts in Marketing Communication (candidate) at the School of Communication Arts, University of the \\ Thai Chamber of Commerce, Thailand \\ 2. Associate Professor and Director of the Doctoral Program in Marketing Communication at the School of \\ Communication Arts, University of the Thai Chamber of Commerce, Thailand
}

\begin{abstract}
The purpose of this research was to study the content on Twitter that Journalists used to create their brand The research population is a research about the journalists' brandings which published during 2011 - 2018 from 2 stories in the database of Thai Journals Online, and 9 stories from Google Scholar, in total 11 stories as well as in-depth interviews with 5 journalists who using Twitter to create their own brands by using Roberto Alcaraz de Blanco (2010)'s personal branding framework as a framework for education. They studied in 7 issues as below; 1) knowledge and experience 2) profiling and displaying positions in the organization 3) presentation of results 4) addiction hashtag 5) communication channels 6) social values and 7) response and context.

The results indicated that knowledge and professional experience in capturing news issues both in writing and reporting news via the limited 140 characters of the Twitter was important. Journalists must also have knowledge and experience about its content. Most of the journalists will report the current news; especially the political violence. For example, in Australia, the journalists in the area will report the news by themselves or monitor news from other media by presenting only short news with attachments, links, images and short video clips and quickly present. The profile setting will use the real name and job positions in the news organization. Anyway, the picture will be a picture that reflects his/her self-characteristics. Completed news will not be presented via Twitter because it's not the area to promote their private life story. Addition Hashtags are often the name of organizations. Twitter, Facebook and Instagram were commonly used to convey messages but in a different way pertaining to specific characteristics of each platform. Followers in Twitter also reflect the groups of people who use social media more focus on political issue and also have a reaction.
\end{abstract}

Keywords: personal branding, journalists, journalistic branding 


\section{Introduction}

The advent of internet changes the process of news and information transmission between sender and receiver. Media platforms were converged from traditional of print media, radio and television broadcasting to digital and online format. This change of platform not only affects the media industry operation at large but also so affects the journalists' works. With the smart communication technology the individual journalists need to re-orient their skills and competency. Media convergence forces the journalists to cover the whole process of news gathering, news writing and reporting the news. Modern journalists must be multi-tasking oriented person as their job requirements are more complicate. Journalists have to work in many duties, including searching and gathering information, interviewing informants and writing news that must be published on multiple platforms or merging it into other media.

Consumers' behaviors also change according to technology. Smartphones have becoming an important communication tool. It is not only a tool for receiving news but it is also a sending device. When the user encounter an important and interesting situations which is worth reporting he/she just pick it up, take pictures and share them online. A receiver performs a journalist's duty. This active receiver became people journalist. The people journalist is not the only threat to the journalist but also facing competition among the fellow journalists in the same organization as well as from other news agencies. Personal branding has become an important strategy for the journalists to differentiate themselves and crafting their identity. In this social media era most journalists choose Twitter, Facebook, and Instagram to communicate their messages, news story as well as personal story which could form their brand image or identity. Each journalist will use communication channels from his knowledge and expertise. Journalists do not work in isolation but as a member of an organization they are affiliated with. Organization affiliation, therefore, is an important factor in journalistic branding.

Among the aforementioned platforms used, Twitter was reportedly used most among journalists (Wongsakorn, 2013) therefore content analysis of the researches on the uses of Twitter by journalists and in-depth interview with key informants could increase knowledge on presentation techniques and message strategy use to create personal branding of the journalists.

\section{Research Questions}

1. What is the content on Twitter that journalists use to create their brands?

\section{Research Objectives}

1. To study the content on Twitter that journalists use to create their brands.

\section{Significance of the study}

The research results shed light on the content strategy used by the journalists in creating their brands via Twitter. The research framework used to analyze the data could be used to guide future research to confirm the message strategy in creating journalists' branding. 


\section{Conceptual framework}

The personal branding elements identified by Roberto Alvarez de Blanco (2010) were modified to form analytical factors in constructing the research instruments. These factors included 1) knowledge and experience in presenting content on Twitter, 2) setting profiles and displaying positions in organizations on Twitter, 3) presentation, receiving awards on Twitter, 4) addiction Hashtag on Twitter, 5) communication channels, 6) social values, and 7) response and context on Twitter.

\section{Research Methodology}

This qualitative research used mix-method to collect data, content analysis and in-depth interview. The details were as follows;

\section{Population and sample}

There were two groups of population in this study.

1. Documents. The research paper concerning the uses of Twitter published during the year $2011-2018$ were included in this research. Keywords used to locate the population included; branding, journalists, journalists' branding. The search yield 2 papers from ThaiJo database, and 17,600 papers from the Google Scholar. Further screening for inclusion yield that there are 9 eligible research papers that correspond with journalists' branding via Twitter; therefore, 11 articles complete the document sample.

2. Journalist. The key informant were recruited from the journalists who known as social media users. The inclusion criteria of the sample journalists were 1) used Twitter in reporting news at least 10 years and having $>100,000$ followers in Twitter. The purposive sampling was used to select the sample. Only five journalists were qualified to be recruited as details in Table 1 below.

Table 1 : List of key informants

\begin{tabular}{|l|l|c|}
\hline \multicolumn{1}{|c|}{ Main Informants } & \multicolumn{1}{c|}{ Profile Name } & Number of followers on Twitter \\
\hline Thapanee Eadsrichai & @Thapanee3Miti & 940,000 \\
\hline Dr. Nattha Kamolwatin & @Nathha_ThaiPBS & 290,000 \\
\hline Bandit Chanthasridum & @ can_nw & 145,000 \\
\hline Bussarin Worasmith & @ Bussarin_PPTV & 144,000 \\
\hline Satian Virayapanpongsa & @ satian_pptv & 117,000 \\
\hline
\end{tabular}

\section{Research instruments}

Two research instruments were constructed to collect data from the samples.

1. Coding form. The questions were divided into 2 sections. Section 1 collected the profiling data of the research papers; 1) Bibliographic data of the research (title, researcher name, publication year, 2) research objectives, 3) research methods (research tools, concepts and related theories), and 4) research findings. Section 2 comprised of 7 factors used to guide content analysis 
of the research papers; 1) Knowledge and experience in presenting content on Twitter; 2) setting profiles and displaying positions in organizations on Twitter;

3) presentation, receiving awards on Twitter; 4) addiction Hashtag on Twitter; 5) communication channels; 6) social values; and 7) response and context on Twitter.

2. Interview guide. This instrument was used to collect data from key informants. Seven questions similar to the questions in section 2 of the coding form were used to guide an in-depth interview.

\section{Data collection and research presentation}

The researcher used the coding form to collected data from 11 research papers. In-depth interviews were conducted. Tape recording was used with the key informants' permission to record the interviewing. The interviews last between 45-100 minutes. Data collection was conducted during April - May 2019. The interview was transcribed verbatim and content analyses. Data from coding form and interview transcribed were analyzed together. The findings were presented in descriptive with quotation to enumerate the details of the findings.

\section{Results and Discussion}

\subsection{Researches on the uses of Twitter by the journalists}

It was found that most of the research papers (8 papers) focused on studying composition and branding of the journalists in total 8 papers, followed by the way of communication in journalists' branding, the researcher studied the branding of five journalists in five research papers. The objectives of the study were 1) to study the journalists' brandings, 2) to study the perception of media organization management, 3) to study the influence and motivation of journalists' brandings, 4) to know the differences of the demographic of journalists on the creation of individual branding, and5) to study how to remain the branding and study the impact of journalists' brandings in 1 story. The research methodology, it was found that most of the six papers used mixed methods, followed by qualitative research (4 papers), and 1 quantitative research. On research instruments used were content analysis ( 8 papers), followed by using the questionnaire ( 5 papers), three in-depth interview, two semi-structured interviews and two interviews.

The synthesis of concepts can be categorized as 8 major research groups and found that the most common concepts and theories were Brand Building of Philip Kotler (2003), personal branding (2010) of Roberto Alvarez de Blanco (10 papers), 7 social media concepts, 5 papers of news concept, 3 concepts of Erikson's identity creation (1968) \& Goffman (1959), 2 concepts of cross-media communication, 1 perception theory, and 1 discourse and identity theory of Laclu and Mouffe (1985). 


\section{Conceptual framework}

\begin{tabular}{|l|}
\hline \multicolumn{1}{|c|}{ Concept } \\
The concept of \\
journalists' \\
brandings of \\
Roberto Alvarez \\
de Blanco(2010)
\end{tabular}

\begin{tabular}{l}
\multicolumn{1}{c}{ Study Factors } \\
1) Knowledge and experience \\
2) Profiling and displaying \\
positions in the organization \\
3) Presentation of results \\
4) Addiction hashtag \\
5) Communication channels \\
6) Social values \\
7) Response and context
\end{tabular}

\subsection{The Content of the Twitter}

\subsubsection{Knowledge and experience}

The study results of communication reflected the knowledge and experience of journalists which found in 6 research papers and from in-depth interviews. There are 2 issues: 1) knowledge and professional experience in capturing news issues both in writing and reports via Twitter by summarizing the content, including details, and analysis the news within 140 characters. 2) About knowledge and experience about its content. Most of the Journalists will report the current news; especially the political violence. such as, in Australia, the journalists in the area will report the news by themselves or monitor news from other medias by presenting only short news with attachments, links, images and short video clips and quickly present. such as : Thapanee, Satian, and Bussarin, they take out details of the news, some knowledge from what they saw in their daily life or from their works and post them on Twitter for at least 10 years; therefore, the expertise and experience in using Twitter can trigger their own brandings. Thapanee, Bandit, Satian, and Bussarin, who specialize in political news, take out their working experience to analyze political and international news. 


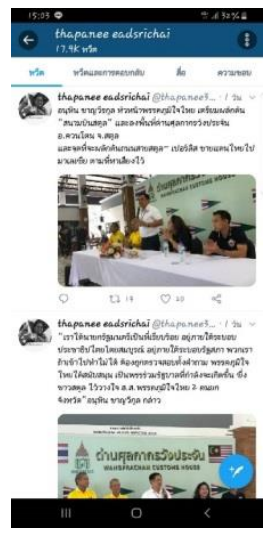

“...Will tweet the news that I did, I saw, I hear myself as a headline because I am on behalf of social media, I need to be the that area and be reliable..."

(Thapanee Eadsrichai, Interviewed on 8 June 2019)

Picture 1 Thapanee’s Twitter profile page @Thapanee3Miti

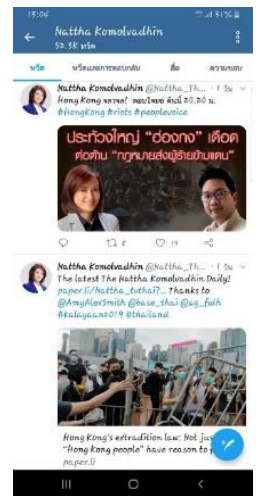

“... Normally I will take information from other medias like Thai PBS channel and put it into Twitter. Especially international news because I am interested in international news..."

(Dr. Nattha Kamolwatin. Interviewed on 11 June 2019)

Picture 2 Nattha's Twitter profile page @Nathha_ThaiPBS

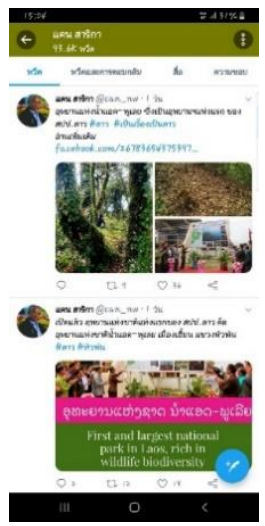

“... When mass media have to present news in various channels, journalists have to write the content into Twitter as well by attaching images and Facebook links because Twitter can copy only a few words. ..."

(Bandit Chanthasridum, Interviewed on 13 June 2019) 


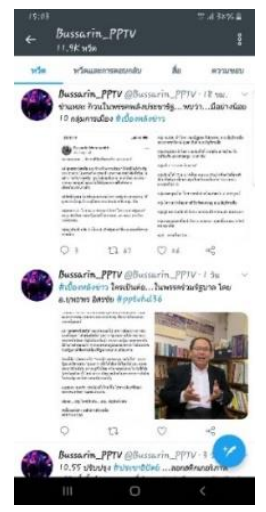

"... Twitter needs only short text; therefore, I use capture text to write political news and analysis on Twitter which made the followers read the news completely. ..."

(Bussarin Worasmith, Interviewed on 10 June 2019)

Picture 4 : Bussarin’s Twitter profile page @Bussarin_PPTV

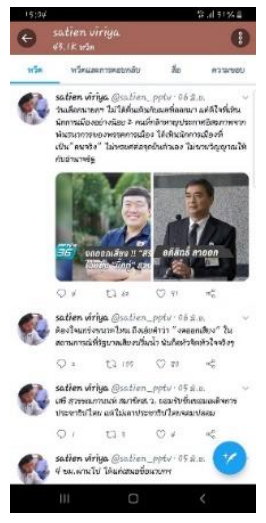

“... Now my role has changed from field journalists to management. I will gather all information from the reporters to analyze before tweeting to balance the news because today our society is in conflict and have different opinions. ..."

(Satian Virayapanpongsa, Interviewed on 10 June 2019)

Picture 5:Satian's Twitter profile page @ satian_pptv

In order to do in-time news presentation, the reporters from newspaper, and TV need to adapt themselves to the modern era and in line with the news organization until they become convergence journalists which are responsible for reporting through multi platforms by using the efficiency of modern news equipment altogether with modern communication technology.

\subsubsection{Profiling and Displaying Positions in the Organization}

It was found that profiling and displaying positions in the organization on Twitter will reflect journalists' brandings. There were 3 research papers and 5 key informants uers, setting their profiles that reveal personal information; for example, real name, last name and job title in 
the organization. On Thapanee's Twitter, she used her workplace picture in black and white color. For Nattha's profile, she used her picture with bright suit jacket to create her credibility but not too stressful. Similarly, Satian's profile, he uses his picture while talking on the phone because he

thinks the reporter match with cell phone. For Busarin's profile, she used her picture to reflect her liveliness and Bandit uses his normal pictures. All five key informants rarely changed their profile picture that is to create a memorable image for followers as the below example profile pictures.

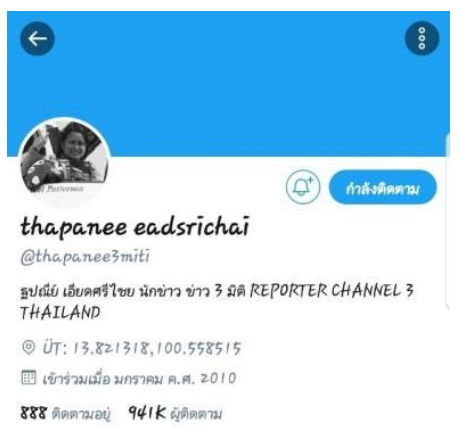

Picture 6 Thapanee's profile page

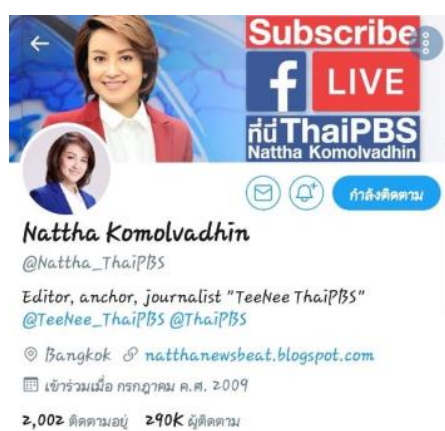

Picture 7 Nattha's profile page

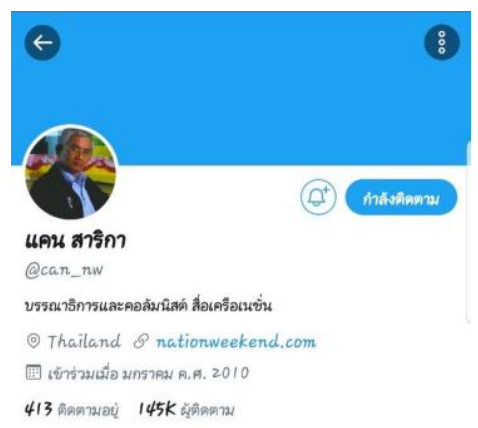

Picture 8 Bandit's profile page

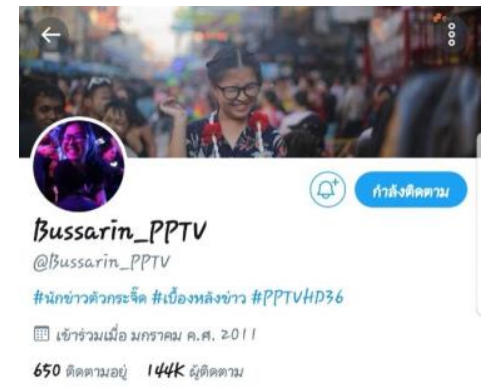

Picture 9 Bussarin's profile page

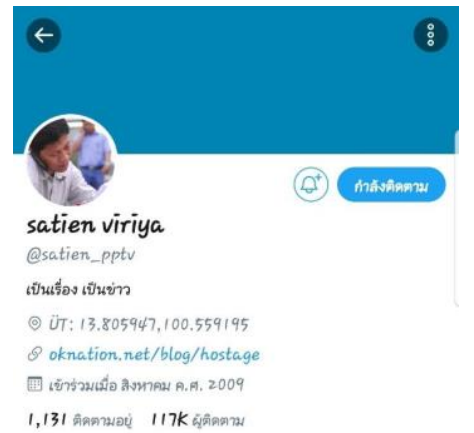

Picture 10 Satian's profile page

\subsubsection{The Presentations \& Receiving Awards on Twitter}

Result from content analysis and from interviewing revealed no data concerning the success or reward of the journalist's new on Twitter. Data from interviews indicated that the journalists did not think it is appropriate to tweet private story. Receiving award is consider private information not news. 
“... Normally I use Twitter only for presenting a urgent news, not my own personal story because I want Twitter is the only news channel...."

(Thapanee Eadsrichai, Interviewed on 8 June 2019)

“... In the past, I have got many awards both the best female journalist award and Human Rights Award but did not tweet via Twitter but will tweet the information of the awards altogether with the committee. ..."

(Dr. Nattha Kamolwatin. Interviewed on 11 June 2019)

“... I have never tweeted my prize because Twitter is a society for following news, not for promoting myself. Anyway, I will use other communication channels to present myself. ..."

(Bandit Chanthasridum, Interviewed on 13 June 2019)

“... The goal of using Twitter is not for promoting my rewards but I will share it on my Facebook because Twitter is a media which lacks of privacy...."

(Bussarin Worasmith, Interviewed on 10 June 2019)

“... Once receiving awards, I have never tweeted because Twitter isn't used for promoting myself and I also don't care about my image but I am just a journalist who love to present news only. ..."

(Satian Virayapanpongsa, Interviewed on 10 June 2019)

\subsubsection{Twitter Hashtag Addiction}

The results from research papers and interviews revealed that the hashtag was used to identify the news organization which is an organization's core policy for creating 
journalists and organizations' brandings. The journalists must present the news via Twitter and other platforms, along with organization hashtags and name of programmed hashtags, and core issues of the news. The news organization will consider the suitability of journalists' work but will not force journalists to strictly follow because journalists have to perform many duties.

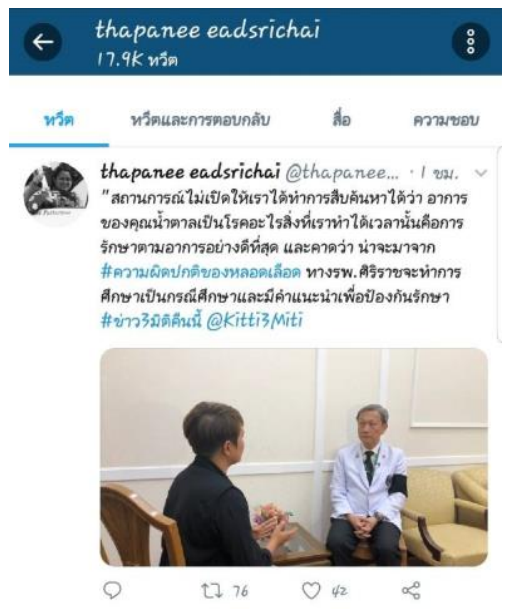

Picture 11 Thapanee's Hastage

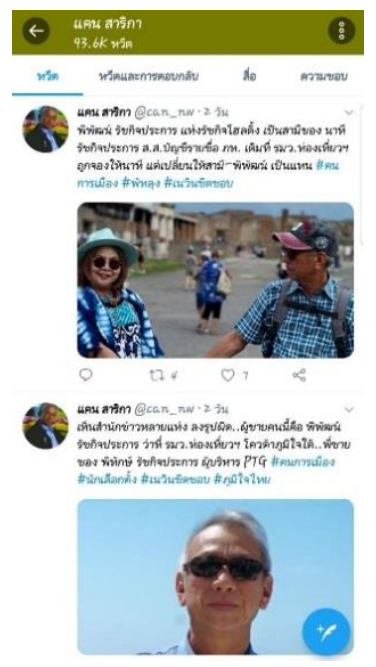

Picture 13 Bandit's Hastage

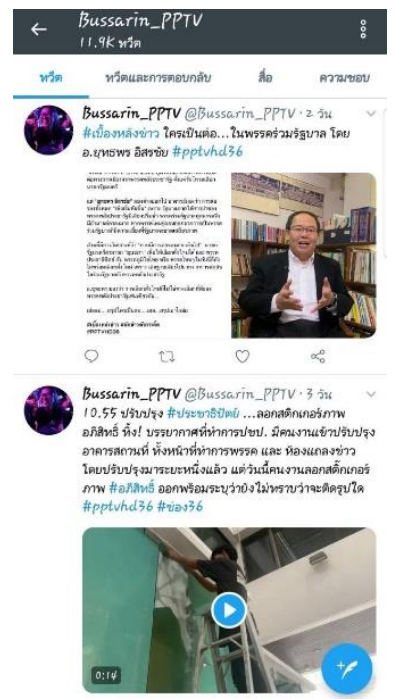

Picture 14 Bussarin's Hastage

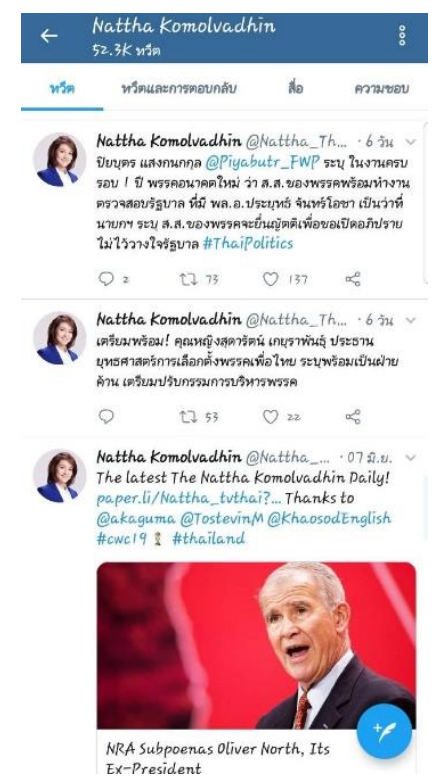

Picture 12 Nattha's Hastage

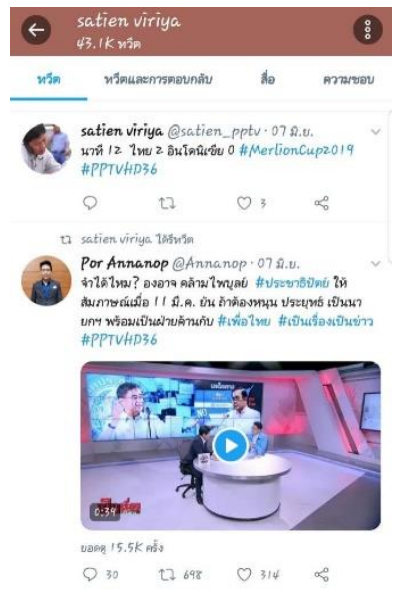

Picture 15 Satian's Hastage

News organizations are an important part of the journalists' branding because journalists are considered an important mechanism in producing news for the organization. The reporters are the 
work force who work on the field to find the quality raw materials to cook. If getting good quality raw materials, the organization will receive good results as well. Therefore, the hashtag is a reflection of the journalists' resources

\subsubsection{Communication Channel}

Data analysis revealed that Twitter isn't an only one channel to present the news but it also has Facebook or Facebook fan page. If news content is contained more detail than Twitter. Facebook and Instagram are also a way to present the detail of news and personal stories in everyday life as well. In particular, It was found that Busarin always tweet her private life story more than her counterparts.

\subsubsection{Social Values}

Data from content analysis revealed that in Australian Twitter followers most likely followed political news. Data from interview explained this phenomena especially idea and comments from the veteran journalist in the field. All key informants confirmed that the followers would have higher expectation to get more profound analysis and story between the line. Nattha also viewed that Twitter is also a source of influential people or influencers who use Twitter to create their own branding. Bussarin and Satain also stated that people in the society were truly aware of receiving information from journalists or mass media because they are afraid of fake news. They also create a large community to exchange the information with each other. Therefore, journalists are no longer the only messenger anymore but they also become recipients.

\subsubsection{Response and context}

The findings indicated that responding to follower comments conveyed the owner's brand. It was found that the foreign journalists who continued theirs tweets and always responded to followers' comments could keep their brand alive. Continuity of interaction could strengthen bonding and increase followers loyalty. All key informants confirmed that tweeting interesting issue and new for a long time increased the number of followers. However, all key informants did not always respond to their followers. Thapanee, she tweeted a news about political issues, she eventually became a political tools of the other party as someone will distort messages to create hatred. Once it happened she would stop posting for 1-2 days to reduce the resistance. Then she will tweet again by maintaining the same standard of work under her credibility and social responsibility. For Nattha, Bandit, and Satian, they have never tweeted their personal stories which cause the questions from the followers that 3 journalists really work for 24 hours or not. 3 journalists just consider that Twitter is a private in public areas or called "Private in Public Space" 


\section{Suggestion}

Based on the finding, two suggestions were initiated as follows.

1) This study is limited to analysis of the message thus further study from the followers' views would increase understanding of the journalistic branding at large.

2) Twitter is not the only social media platform used by the journalists. This platform has limitation in the length of the message whereas other platform like Facebook, Instagram and Podcasts have similar disadvantages. These platforms are also getting popularity among journalist. Studying the uses of those platforms would shed some light on the alternative branding instrument for journalists. 


\section{References}

[1] Brems, C., T., M., Graham, T., \& Broersma, M. (2016). Personal branding on Twitter. Digital Journalism. Epub ahead of print. doi:10.1080/21670811.2016.1176534

[2] Bruns, A. (2012). Journalists and Twitter: How Australian News Organizations Adapt to a New Medium. Media International Australia, 144(1), 97-107. https://doi.org/10.1177/1329878X1214400114

[3] Hanusch, F., \& Bruns, A. (2017). Journalistic Branding on Twitter: A representative study of Australian journalists' profile descriptions. Digital Journalism, 5(1), 26-43.

[4] Hedman, U. (2016). When journalists tweet: Disclosure, participatory, and personal transparency. Social Media+ Society.

[10] Holton, A. E., \& Lewis, S. C. (2011). Journalists, social media, and the use of humor on

Twitter. Electronic Journal of Communication, 21(1/2), 1-22.

[11] Holton, A. \& Logan Molyneux (2015) Identity lost? The personal impact of brand journalism. Digital Journalism,

file:///D:/PhD/Thesis/lit\%20review/การสร้างแบรนด์บุคคล/

Eng/Journalist\%20Branding/systematic\%20review/identity\%20lost\%20The\%20personal $\% 20$ impact $\% 20$ of\%20brand\%20journalism..pdf

[12] Molyneux, L., Holton, A., \& Lewis, S. C. (2018). How journalists engage in branding on Twitter: Individual, organizational, and institutional levels. Information, Communication \& Society, 21(10), 1386-1401.

[13] Olausson, U. (2017). The reinvented journalist: The discursive construction of professional identity on Twitter. Digital Journalism, 5(1), 61-81.

[14] Picard, R. G. (2015). Journalists' perceptions of the future of journalistic work. Reuters Institute for the Study of Journalism.

[15] Wongsakorn Sansaneerat (2013). Field journalists' branding via Twitter. Doctoral Dissertation, Chulalongkorn University. 